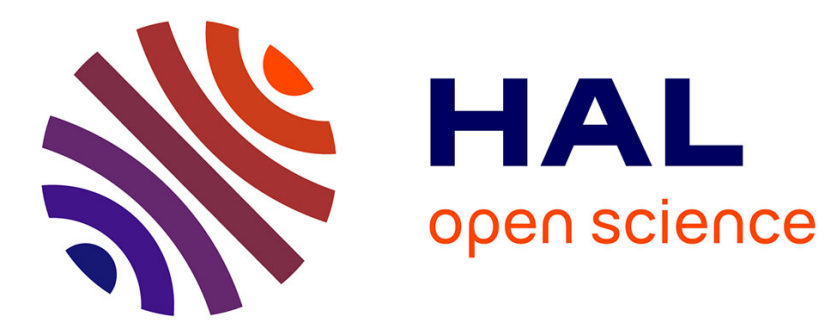

\title{
Regional integration and maritime connectivity across the Maghreb seaport system
}

\author{
Fatima Z. Mohamed-Chérif, César Ducruet
}

\section{To cite this version:}

Fatima Z. Mohamed-Chérif, César Ducruet. Regional integration and maritime connectivity across the Maghreb seaport system. Journal of Transport Geography, 2016, 51, pp.280-293. 10.1016/j.jtrangeo.2015.01.013 . halshs-01145664

\section{HAL Id: halshs-01145664 \\ https://shs.hal.science/halshs-01145664}

Submitted on 2 Sep 2016

HAL is a multi-disciplinary open access archive for the deposit and dissemination of scientific research documents, whether they are published or not. The documents may come from teaching and research institutions in France or abroad, or from public or private research centers.
L'archive ouverte pluridisciplinaire HAL, est destinée au dépôt et à la diffusion de documents scientifiques de niveau recherche, publiés ou non, émanant des établissements d'enseignement et de recherche français ou étrangers, des laboratoires publics ou privés. 


\title{
Regional integration and maritime connectivity across the Maghreb seaport system
}

Pre-final version of the article published in Journal of Transport Geography, 51: 280-193.

\author{
Fatima Mohamed-Chérif \\ Ecole Supérieure Maritime \\ Bou-Ismail, Algeria \\ fzmedcherif31000@yahoo.fr
}

\author{
César Ducruet \\ French National Centre for Scientific Research (CNRS) \\ UMR 8504 Géographie-Cités, Paris, France \\ cdu@parisgeo.cnrs.fr
}

\begin{abstract}
Models and empirical studies of port system evolution dominantly focus on land-based dynamics. Hence, it is traditionally recognized that such dynamics condition the evolution of ports and their relations as well as wider regional integration processes. The Maghreb region (Algeria, Morocco, and Tunisia), which is currently responsible for no less than one-third of all African port throughputs, offers a fertile ground to test the possibility for regional integration to occur through maritime linkages despite limited trade integration and landbased transport connectivity. Main results highlight the increase of trans-Maghreb maritime connectivity but this occurs mostly at the periphery of the system based on transit flows. Logistical integration versus trade integration is discussed in light of the recent evolution of Maghreb ports and of the region in general.
\end{abstract}

Keywords: Maritime network; North Africa; Port system; Regional integration 


\section{Introduction}

The combined throughputs of Maghreb ports totaled 228 and 214 million tons in 2008 and 2009 respectively (Journal de la Marine Marchande, 2010), thereby accounting for no less than one-third of all African port throughputs, and one-fifth of all African container port throughputs $^{1}$. Such an importance is, surprisingly, not reflected in the literature on ports and port systems, since the Maghreb region - taken as a whole and even by country - has never been systematically studied. No one single paper on Maghreb ports was reported by an extensive review of nearly 400 papers about ports published in major geographical journals since 1950, while the number of papers on African ports in general has dropped significantly over this period ( $\mathrm{Ng}$ and Ducruet, 2014). More likely are works on the East African (Hoyle and Charlier, 1995), West African (Taaffe et al., 1963; Hilling, 1969, 1977), and South African (Notteboom, 2011) port systems, while recent studies of the Mediterranean port system barely mention Maghreb ports (see Gouvernal et al., 2005).

One likely reason is the traditionally low containerization rate of Maghreb ports due to the overwhelming dominance of bulk exports (e.g. oil, gas, and minerals) in total port activity. Other reasons are the absence of contestable hinterlands and the wide discrepancies among Maghreb ports in terms of technical and managerial efficiency that hamper the emergence of a coherent port system or maritime range. For instance, Algerian ports are often seen as costly and congested in official reports (Ocean Shipping Consultants, 2009) while Algeria as a whole has the lowest logistical performance index among Maghreb countries ${ }^{2}$. Maghreb ports in general have long suffered from lacks of investments in modern infrastructure, land-use problems within large cities, limited hinterland accessibility, poor technical efficiency and cumbersome customs regulations fostering transport costs (Ulied and Bosca, 2008; El Khayat, 2014). This accentuates the gap with global transport standards as well as the contradiction between a strong reliance of Maghreb's international trade upon sea transport (about 95\%) and the poor conditions of its port infrastructures (Tourret, 2005).

\footnotetext{
${ }^{1}$ This paper focuses on the central part of the Greater Maghreb which comprises Mauritania, Morocco, Algeria, Tunisia, and Libya. This choice is motivated by physical geography (Atlas Mountains and coastal areas) and its influence on the layout of transport infrastructure as well as by contemporary history that resulted in more similarities between Algeria, Tunisia, and Morocco than with their neighbors since French colonial rule. Although the Arab Maghreb Union formed in 1989 included the five countries, the Greater Maghreb is often seen as "a somewhat artificial construct because Libya and Mauritania do not have the same history and geographic configuration than the smaller Maghreb" (Cote, 1996, p. 6).

2 The World Bank (2007) has released the following indices for Maghreb countries: Tunisia (2.76), Morocco (2.38), and Algeria (2.06).
} 
Signs of progress in the ports and maritime sector have appeared recently, however, through both large-scale port development projects and reforms. For instance, there are plans to improve regional land-based connectivity through a trans-Maghreb highway and railway, while each country promotes port modernization and competition by developing its own transhipment hub and dry ports. Notably, the involvement of large port operators such as APM Terminals, PSA, Eurogate, and Dubai as well as terminal concessions awarded to Maersk, CMA-CGM, and MSC are clear illustrations of ongoing changes (Invest in Med, 2009). While accessing original information about the activities of Maghreb ports remains difficult, this research was able to condense dispersed data on port traffics and to compile previously untouched statistics on vessel movements between Maghreb ports over the last 120 years to offer a new perspective on port system dynamics. Other efforts were put on synthesizing a large number of recent articles, reports, and conference papers on Maghreb ports that were critically examined through direct interviews with local port authorities. Issues of port governance, notably in terms of the applicability of certain standards and models to the Maghreb, are discussed in light of recent mainstream works on the matter (see Brooks and Cullinane, 2006; Sanchez and Wilmsmeier, 2010).

The wider theoretical issues explored by this research are related with the relationship between maritime network design and regional integration, which has not been much explored in the scientific literature. Most of port systems studies have remained focused on individual port traffics of ports and hinterland dynamics: "in their preoccupation with the development of land communications (...) the authors neglected the development of maritime space" (Rimmer, 2007, p. 76), although the concept of maritime range is also based on shared maritime connectivity among neighboring ports (Vigarié, 1979) as well as information system integration (Lemarchand and Joly, 2009). Yet, it should be acknowledged that a recent surge of interest for the study of maritime flows gave birth to numerous works by geographers and other scientists (see Ducruet, 2013 for a review). The role of geographic proximity in the distribution of inter-port maritime flows has been explored at the scale of the Atlantic Ocean (Ducruet et al., 2010) and the world (Ducruet and Zaidi, 2012), but not sufficiently discussed in light of local port and wider economic and trade dynamics. Some exceptions remain, such as for Southern Africa (Iheduru, 1996; Fraser et al., 2014) or the Korean peninsula (Ducruet, 2008). The latter work demonstrated that the growth and multiplication of maritime linkages between neighbor countries may also occur despite political tensions and limited trade, due to the precedence taken by logistical factors. Strong regional integration may foster network concentration through hub-and-spokes systems rather than more homogenous, port-to-port or 
polycentric systems as seen in the marked differences between Northern and Southern Europe (Ducruet, 2010). Conversely, regional integration is approached at the level of trade flows between countries to verify whether neighbor countries trade more with each other than with others, or through the concept of territorial integration using more qualitative methods to analyze transport infrastructures and wider socio-economic trends (Lajugie et al., 1985; Burmeister and Joignaux, 1997), based on the idea of the region as a homogenous and functionally integrated area.

The extent to which the design of maritime networks overlaps or transgresses the pattern of trade (and wider cultural, political) relationships thus remains largely unexplored. Maritime networks may develop in drastically different ways, with or without regional integration, depending on the context. The Maghreb region is a good case for such an investigation given its strong reliance upon maritime transport for foreign trade, and the absence of an official, namely diplomatic and political, integration. The remainder of the paper is organized as follows. The second section provides a more complete background on Maghreb ports in order to better explain their evolution, current deficiencies and potentials. In the third section, we examine recent policies and recent development projects as well as trends in the distribution and performance of port traffics both locally and regionally. The core of the analysis lies in the fourth section, with an analysis of maritime dynamics taking place across the Maghreb. Finally, the conclusion discusses the implications of the results for further Maghreb integration.

\section{Background on Maghreb ports}

\subsection{General profile of the Maghreb region}

The Maghreb is still nowadays little integrated, since only $7-8 \%$ of its total trade is intraregional and this intra-regional trade concentrates only 3.5\% of the region's GDP, against 26\% for East Asia and North America, 16\% in Europe, and 6\% in Latin America (Romagnoli and Mengoni, 2009). Several factors contribute to this state of affairs, such as the heterogeneity of economic conditions, the limited internationalization, a strong specialization on natural resources and low valued goods, and the polarization of external trade flows by Western European countries. Limited regional integration also stems from inherited political tensions across the Maghreb, protectionism, tariff barriers, and the rather low connectivity of land-based transport systems. The current situation is partly inherited from the past. During the French colonial rule (19th-20th centuries), plans for a wider Maghreb integration including the Sahara were abandoned and development was restricted to areas along the coast 
near the metropolis (Côte, 1988). Most of the capital and largest cities are situated near the coast (i.e. Rabat, Algiers, Tunis, Casablanca, Agadir, Oran, and Tangier) except Fes, Marrakech, and Constantine. In Algeria, the coastal area represents only 2\% of the country's total surface but concentrates about $40 \%$ of its population. While the urbanization rate of Tunisia (64\%) is the highest (Belhedi, 2005), population density along Morocco's Atlantic coast between Kenitra and Casablanca reaches 160 inhabitants per square kilometers against 90 on average in the Mediterranean basin, thereby accentuating spatial and socio-economic disparities between coastal and inland areas (Troin, 2006; Lacoste, 2007).

Although the limited economic complementarity is often given as the main explanation of limited trans-Maghreb trade exchanges and thus of regional integration (Bensidoun and Chevalier, 1996), there remains certain ambiguities such as Logan automobiles being distributed in Algeria but built in Romania despite the installation of a vehicle assembly plant by Renault at Tanger (Morocco) since 2012. Geopolitical tensions between the two countries and the decennial civil war experienced by Algeria are perhaps more prevalent in such a state of affairs than pure economic factors.

\subsection{Traffic evolution and specialization}

As in many other emerging countries, maritime transport concentrates most of Maghreb's international trade, thereby putting ports at center stage in regional development issues such as in Western Africa during and after the colonial period (Debrie et al., 2003). Paradoxically, port infrastructures have been little modernized since the 1960s, thus hampering further internationalization due to overarching logistics costs (Tourret, 2005; Frémont, 2010).

Overall, Algeria largely dominates the two other countries by the weight of its total throughput (Figure 1), followed by Morocco and Tunisia. The extraversion of flows is directly reflected in traffic imbalance between import and export, with two-thirds of Tunisian (30 million tons) and Moroccan (60 million tons) traffics being imported and more than $75 \%$ of Algerian traffic (130 million tons) being exported in 2008. The lighter weight of Tunisia comes from the dominance of finished and semi-finished goods such as textiles, as the Maghreb also exports important volumes of solid bulks (e.g. mining products such as phosphates). The specific situation of Algeria is explained by the strong importance of liquid bulks in total port traffics (Figure 2), while Algiers city alone concentrates about $40 \%$ of the country's general cargo traffic. The share of Algerian exports in total port traffics excluding oil and gas had dropped dramatically since the 1960s, oscillating around $10 \%$ only since the 1980s. Gas and oil products indeed occupy an enormous place in Algeria's economy in 
general. Liquefied gas is transferred principally via Arzew and Skikda ports and stored on large vessels heading for Europe, i.e. eight large chemical vessels of about 175,000 cubic meters. There are plans to ship traffic through pipelines towards Spain (Medgaz) and Italy (Galsi: Gasdotto Algeria Sardegna Italia) (El Watan, 2011), the first project being already operational and the second to be completed in 2015, as well as to exploit additional reserves (e.g. Gassi Touil) and to open new chemical plants (Skikda) in 2012. Morocco, the world's third producer and first exporter of phosphates with 20 million tons a year, principally transfers such materials through Casablanca (Khourigba mine), Safi (Youssoufia mine), and the new bulk port of Jorf Lasfar. Tunisia as well exploits phosphates, which are exported via railway and Gabes port (Gafsa mine). This traffic has fostered the development of an important chemicals cluster in Tunisia (4,500 jobs) around the production of fertilizers and acids, notwithstanding environmental degradation of coastal zones (Lahlou, 2010). Other products exported by Morocco and Tunisia include agricultural goods based on intensive production systems, but Algeria is still largely importing such products.

The apparent dynamist of Algeria is better related to a growing dependence over bulk exports. Comparatively, general cargo traffic remains mostly imported due to a weak agricultural and industrial base, and high transport costs. General cargo exports have thus decreased in relative terms from $90 \%$ (1952) to 52\% (1962) and 14\% (2009) of total traffics (excluding liquid bulks). Rapid traffic growth at Algerian ports since 1997 (Figure 1) is probably less explained by the economic policies (the so-called "transition period") led by presidents Zéroual and Bouteflika than by reinforced specialization and exports of natural resources due to growing European and global demands (see also Table 2).

Due to congestion in Algiers, traffic has shifted to Bejaia, which container throughput increased tremendously between 2001 and 2013 (Table 3), while smaller ports as well have witnessed noticeable traffic growth. This has resulted in the regular de-concentration of container throughputs as seen with the lowering Gini coefficient and Hirschman-Herfindahl index over the period.

[Insert Figure 1 about here]

[Insert Figure 2 about here]

[Insert Tables 1, 2, 3 about here]

\subsection{Logistics issues}

\subsubsection{Transport chains and hinterlands}


The dominant North-South orientation of commercial flows connecting the Maghreb as well as the relative failure of integration initiatives launched in 1989 (Arab Maghreb Union) are still reflected in the spatial organization of transport systems in the region (Benabderrazik, 2008). The closure of the Morocco-Algeria border, maintained customs barriers, as well as the limited interconnexion of railways and expressways across the three countries all contribute to the low integration of logistics systems (Figure 3). The concentration of land-based transport systems along the coast accentuates congestion problems notably in seaports, and restrains the development of multimodal transport.

[Insert Figure 3 about here]

Protectionism leads to a majority of captive hinterlands whereby each port serves its immediate local and/or national hinterland (Mohamed-Chérif, 2008). However, several recurrent problems are of increasing concern. First, the efficiency of the transport chain remains rather low compared with international standards, notably due to cumbersome port operations by public authorities (maintenance costs, lengthy customs procedures, low participation of the private sector) and higher maritime transport costs than to/from other Mediterranean regions (Ulied, Bosca, 2008). Second, the absence of a coherent logistics chain connecting Maghreb countries increases overall transport costs due to the weight of containers returning empty, insufficient consolidation systems, and high administrative fees for intraMaghreb exchanges. Third, the involvement of domestic ocean carriers in international shipping remains rather limited, due to a monopolistic situation whereby each national transport company remains specialized in one specific type of goods, while national fleets are ageing except for recently built Algerian chemicals vessels.

Despite the limitations of land transport and as one consequence of low integration, coastal shipping across the Maghreb remains limited. More than $60 \%$ of Maghreb's international trade is realized with the European Union. Food products and manufactured goods dominate North-South flows and bulks (notably gas and oil products) dominate South-North flows. In addition, the containerized ratio of port traffic is about $25 \%$ for Algeria, $30 \%$ for Tunisia, and 45\% for Morocco (Mohammed-Chérif, 2008). Still for Morocco, about 41\% of outbound containers remain empty, as its exports remain mostly raw materials.

Ship operators fix their tariffs not only depending on the conditions of destination ports, but also based upon foreseeable risks for vessels to overstay in the port. Penalties (surestaries) increase the transport bill paid in the end by the consumer. For instance, the cost of 
transporting one 20 twenty-foot container is the same (about 1,100 euros) between Marseilles and Algiers and between Marseilles and Tunis despite a longer distance of the latter route. Surestaries have constituted important financial losses for decades in Algeria. It is frequent for Algiers port to have 25-30 vessels waiting outside the harbor and sometimes this number can reach 45. Contrarily, when a vessel is freed sooner than expected, the Algerian customer may get a bonus called dispatch money, but this remains limited in practice due to a lack of knowledge on the matter by both import-export companies and foreign trade administrations. Due to surestaries and a bad management of the transport chain, the rate of door-to-door delivery for Algeria remains about 5\% compared with a world average of $15-16 \%$. The value of shipments in some cases reaches $30 \%$ over the initial value, causing about US\$ 3.2 million losses on a yearly basis. Algeria still witnesses a very high cost for either importing or exporting one container (about 1,300 euros) compared with other developing countries, and its "logistics performance index" remains the Maghreb's lowest, ranking under China, Vietnam, and Poland.

\subsubsection{Port activities and maritime accessibility}

Built during the colonial period, most Maghreb ports have long been limited in terms of their water depth and storage facilities. Only vessels up to 20,000 gross tons (GRT) and 400 TEUs can generally call at Maghreb ports (Setti, 2001). For instance in Algeria, Algiers, the largest general cargo port, is not able to welcome 1,200 TEU vessels due to strong limitations of quay length (a maximum of 300 meters) and quay depth (about 11.5 meters). Only Djen Djen port enjoys higher nautical accessibility (about 18 meters) as well as oil ports, while all other Algerian ports reach a limit of 12 meters, most of them being so-called first-generation ports built during the $19^{\text {th }}$ century in large cities (El Khayat, 2014).

The three container terminals created in the 1990s (Algiers, Annaba, and Oran) faced a drastic lack of specialized handling facilities and during several years these terminals remained nothing more than storage areas. Such terminals were long equipped with simple stackers used otherwise for loading rail wagons and without any gantry crane or straddle carriers for containers. This explains why Algiers is still served by feeders rather than mother vessels. On-dock storage is realized along two lines separated by 12 meters and does not surpass three levels of boxes, while modern container terminals often operate based on six lines separated by 4-6 meters reaching six levels of boxes. Only Algiers and Bejaia possess gantry cranes and straddle carriers nowadays, but shipowners regularly complain about the loss of containers during terminal operations (Mohamed-Chérif, 2010). It is also frequent for vessels to be 
ordered to remain in the port arbitrarily in order to levy more taxes. Facilities for unloading and storing cereals are also outdated with a productivity of 200 tons an hour compared with 1,000 to 1,500 tons in modern ports. Such limitations force shipowners to use conventional pallets instead of bulk shipments, which are more economical.

Nautical accessibility problems combine with the lack of space for further port extensions at traditional port cities. In Algiers, the project for developing 42 hectares of container terminals in the Sablettes area finally was replaced by the construction of a sea water recycling plant. Besides the territorial pressures commonly faced by large ports situated in large cities, Algiers has also suffered from losing about half of its surface (i.e. from 126 hectares in the 1970s to 55 hectares nowadays) through urban policies willing to expand circulation and parking areas for automobiles.

In order to relieve Algiers from congestion, the central government decided in 2009 to shift non-containerized cargo to other ports than Algiers, such as roll-on / roll-off and general cargo or bulk vessels sent to Djen Djen and Mostaganem, although the latter ports were not fully equipped to undertake such traffics. One main reason was to de-concentrate traffic in the framework of a national planning policy favoring balanced regional development. Another reason, despite the discontent of domestic economic players, was to free space before the venue of Dubai World Ports (see next sections). Since then, the number of queuing vessels in the bay of Algiers has greatly diminished, from about 30 vessels a day on average in 2009 to 7 in 2010, while peaks may reach a maximum of 13 vessels.

The aforementioned weaknesses in the transport chain are directly reflected in the spatial configuration of shipping networks, notably for containers. The share of transhipment hubs in the overall maritime traffic of Maghreb ports has increased from 19\% to 30\% for direct links and from 8\% to 23\% for direct and indirect links between 1996 and 2006 (Mohamed-Chérif and Ducruet, 2011). Although this corresponds to the rise of intermediate hubs in general in the Mediterranean basin since the mid-1990s, it also reveals a growing weakness of Maghreb ports as seen in their growing level of hub dependence (Ducruet, 2008). In the 1990s, transit was mostly done via Algeciras as Maghreb traffics were primarily connecting West Africa and Northwest Europe (as well as East Mediterranean and Middle East forelands for Tunisia), but also because Algeciras is a traditional gateway for accessing Spain, one of Morocco's main trade partners, and Europe. In the 2000s, hub dependence has increased mostly for Tunisia and Algeria (from 25\% to 40\%) with Marsaxlokk and Cagliari as main hubs to connect East-West trunk routes. Morocco remains far less vulnerable despite a noticeable increase of Marsaxlokk in its maritime connections. Algerian ports are mostly served to and 
from these hubs by feeder vessels of about 300 to 800 TEUs, but recent trends indicate a rapid success of Tangier port due to important reforms and an anticipation policy.

\section{Recent reforms and projects}

3.1 Expanding hinterland connectivity and short-sea shipping

Recent and current policies launched by the three countries seem to converge through a phase of liberalization, the upgrading and expansion of ports, the introduction of competition, structural reforms, as well as an increasing integration of transport and logistics chains. One common goal being the construction of a trans-Maghreb highway and high speed train around 2030 (Brunel and Hufbauer, 2008), one can notice a redefinition of transport plans across the region based on transversal linkages. The Maghreb highway, which will reach 6,850 kilometers from Nouakchott in Mauritania to Tobruk in Libya, should foster exchanges thanks to the connection of more than 50 cities totaling 50 million inhabitants, 22 international airports, and major port and railway nodes of the area. Such a project is part of a wider "transMaghreb multimodal corridor" (MEDA, 2005). Algeria is willing to invest about 7.8 billion euros in the project while the renovation of its railway network will cost 11 billion euros. However, a recent study by CETMO (Centre d'Etudes des Transports en Méditerranée Occidentale) demonstrated a rather low impact of the opening and operation of the new highway on the traffic performance of ports, slightly positive for Algiers and negative elsewhere. The betterment of port transit time was highlighted by the same study as a much more influencing factor than hinterland connectivity in overall port performance. Indeed, the reduction of transit time by one day in Bejaia port would result in $250 \%$ traffic growth, which is corroborated by recent statistics (see section 2).

Another noticeable trend is the port regionalization process (Notteboom and Rodrigue, 2005) underway in the Maghreb. Two dry ports have being developed around the ports of Algiers and Bejaia: Rouiba is operated since 2010 through a collaboration between the Algerian Société Nationale de Transport Ferroviaire (SNTF) and the French ocean carrier CMA-CGM through its Rail Link branch, located 20 kilometers away from the city center, and Bordj Bouarredj respectively. Night rail services between port areas and dry ports allow reducing congestion as well as transport costs. For instance, delivering one container from Marseilles to Rouiba costs 3,150 euros, $20 \%$ lower than the classic truck services. It is also planned to connect Algiers with Mansoura (Bordj Bou Arréridj) located 200 kilometers away and to build a dry port at Sénia near Oran. However, few international logistics companies operate in Algeria, as companies such as DHL, CEVA, and Maersk only keep a small office in Algeria 
compared with warehouses and dedicated zones developed by the same companies in Morocco and Tunisia.

Another promising dynamic is the development of short-sea shipping services to and from Maghreb ports, backed by the Meda Mos (Motorways of the Sea) initiative launched by Europe since 2008 in a spirit of regional integration (Weigert and Abeille, 2010) in a context of optimistic forecasts on maritime traffic growth in the region (Crozet, 2009). Pilot projects have started in 2009 notably including three Maghreb ports (Tangier Med, Tunis-Rades, and Bejaia), thereby benefitting from technical and financial assistance. At the end of 2010, the following lines were operational already: Rades-Genoa and Rades-Marseilles for Tunisia (roll-on / roll-off), Agadir-Port Vendres for Morocco (containers, fruits and vegetables), Bejaia-Barcelona and Bejaia-Marseilles for Algeria (roll-on / roll-off). In addition, Oran port is destined to become the main container port of Western Algeria, with a traffic estimated to reach 500,000 TEUs in 2015 and about 800,000 TEUs in 2025. Port expansion in Oran has already started by extending the container terminal from 12 to 23 hectares and a quay extension from 190 to 490 meters. The Bejaia-Barcelona line in particular will be used for consolidating cargoes at Barcelona port to/from the dry ports of Zaragoza, Madrid (Spain), and Toulouse (France) (Reynaud and Decoupigny, 2008).

\subsection{Port reforms and new port strategies}

Port reforms across the Maghreb have principally served the increased openness towards external players such as global port operators, as well as a new strategy based on the development of transhipment hubs. The Mediterranean basin already counts a number of such transhipment hubs the rapid growth of which largely contributed to the concentration of the regional port system to the detriment of traditional gateway ports (see Ridolfi, 1999; Zohil and Prijon, 1999; Fageda, 2000; Foschi, 2003; Ducruet, 2010). The latter gateway ports often strived since then for enhancing their hinterland accessibility to compensate the loss of direct calls by focusing on railway connections, their essential weakness (Gouvernal et al., 2005) and also by developing European Distribution Centres (EDCs) to better exploit their proximity to mainland markets (Ferrari et al., 2006). The Mediterranean transhipment market is nowadays still highly competitive and monopolized by a few dominant nodes (Tur, 2009) such as Marsaxlokk (Malta), Gioia Tauro, Cagliari, Taranto (Italy), Valencia and Algésiras (Spain), as well as Piraeus (Greece), Limassol (Cyprus), and Damietta (Egypt). Despite this situation, existing large hubs face some difficulties in terms of congestion and cost, thereby making it possible for the entry of outsiders in the market. For the Maghreb, the "crossroads" 
situation can be seen as an opportunity with regard to the fundaments of hub location. Currently, ongoing investments in the Maghreb concerning port expansion plans reach about 507 million euros, which represents $7 \%$ of all transport-related investments in the region (Invest in Med, 2009). Among the three transhipment hub projects concerned (Tangier Med in Morocco, Enfidha in Tunisia, and Djen Djen in Algeria), Tangier-Med and Enfidha occupy $68 \%$ and $19 \%$ of Maghreb's port-related investments respectively. A brief review of the emergence and application of reforms is necessary before presenting in more detail each large-scale project as well as other visible impacts of port reforms in the region.

\subsubsection{Morocco: the Tangier-Med multilayered hub}

Despite its long history as a gateway between Europe and Africa, Tangier has often been seen by Moroccan authorities as a remote place without further potential for development. In the early 1990s however, a new strategy was formulated around the Tangier Atlantic project to build a transhipment port near Asilah city, but this was cancelled in 1999. The choice of modernisation and globalisation since then favoured the elaboration of the Tangier-Med project (Piermay, 2009) launched in 2002 at the estuary of Oued R'mel (40 kilometers East of Tangier city) in order to catch transit trade flows but also relieve Tangier from urban pressure. This project has benefitted from a new national policy notably liberalizing the port sector and privatizing domestic shipping companies. The objective of this project, which started its operations in July 2007, is to handle $85 \%$ of transhipment flows and $15 \%$ of trading flows. The end of the State's monopoly in the port sector was a key component in the realization of the project, strategically located in the Gibraltar Straits to compete with Algeciras (Marei, 2008; Planel, 2009) but without losing its hinterland function (Cherfaoui and Doghmi, 2005). The Tangier-Med project includes the creation of logistics zones (Ksar Sghir dry port) and other free economic zones representing 500 square kilometers and 120,000 direct jobs, as well as a new city planned to host 150,000 inhabitants over 1,300 additional hectares (Ch'rafate). This project thus partly rejuvenates the Tangier-Boukhalef free-zone created in 1997 (Bost, 2010) while favoring regional balance between Atlantic and Mediterranean coasts, notably since the Rif region traditionally suffers from poor infrastructures, unemployment, smuggling, and uncontrolled urban growth (Troin, 2006). The multifunctional port is able to welcome 6,000 TEU vessels with a total capacity of 5 million TEUs. In 2015, at the time of its completion, Tangier-Med should handle 8.5 million TEUs, 7 million passengers, 3 million vehicles, and 10 million tons of liquid bulks. Concessions have been made with global shipping lines such as Maersk, MSC, and CMA-CGM. The whole project should cover 6,000 
hectares in total in a radius of 80 kilometers from the port including industrial parks and other specialized areas.

The logistics-free zone (100 hectares) is thus accompanied by two industrial zones (Meloussa and Tangier), which welcome a Renault factory expected to produce about 170,000 to 400,000 vehicles a year. The free-trade zone of Fnideq (Tetouan province, Sebta region) is developed on 20 hectares of office space and should welcome 500 companies. One issue is the extent to which already established commercial activities in the region will coexist with new, modern activities without causing tensions (Ducruet et al., 2011). Additional special zones are also planned to be developed in the region: Tetouanshore, industrial free zone of Ch'rafate+ (300 hectares, automotive sector), Souq Lakdim industrial zone (150 hectares), and Fnideq commercial zone (140 hectares, wholesale and retail).

One important factor in the success of the whole Tangier-Med project is the improvement of hinterland accessibility through highways (with Rabat and Asilah), expressways (with Tetouan and Fnideq), and railways. Due to high transport costs and reluctance from domestic shippers using Tangier instead of Casablanca, competition between the two ports is likely to remain rather low in the future (Chouiki, 2009), while Tangier could act as a hub for Casablanca on the maritime side. Still, Casablanca handles about $80 \%$ of all Moroccan hinterland traffic, followed by Agadir (12\%) and Tangier (8\%), backed by the proximity of large consumption areas, the weakness of landbased transport infrastructure from Tangier, and the will of the central government to maintain its supremacy. Three major shipping lines convey nearly $80 \%$ of all maritime containers in Morocco (Maersk, CMA CGM, and MSC) while being also port operators, freight forwarders, and logistics agents. Maersk and CMA CGM notably operate two feeder vessels under Moroccan flag between Tangier and Casablanca (Tinghir and Ouez Ziz). This situation also applies to roll-on / roll-off traffic, which at Tangier is mostly exported from the local industries, and imported via Casablanca for the rest of the country (Chaudier, 2014). Despite its shorter distance to Europe for such a traffic and its status of container hub, Tangier remains underperforming compared with Casablanca on such shortsea lines.

Although the 2006 port governance reform and the establishment of a competition comittee in 2008 both aimed to boost the national economy through more competition, the two ports are in practice managed against competition (El Khayat, 2013). The local stevedoring company Marsa Maroc, already in a dominant position within Casablanca port, obtained in 2008 a concession for the TC4 container terminal in Tangier Med II and the agreement to create a subsidiary named Marsa International Tangier Terminal (MINTT) by 2015. The two port 
authorities Agence Nationale des Ports (ANP) and Agence Spéciale Tanger Méditerranée (TMSA) do not have the power to go against such a quasi-monopoly in the local container handling business, which protects Casablanca against competition from Tangier. The entry of Marsa Maroc on the stock market with a privatisation of $30 \%$ of its capital may even more sttrengthen its national leadership.

\subsubsection{Algeria: Dubai Ports World and Portek at Algiers, Djen Djen, and Bejaia ports}

Although it appears that the Algerian port reform has directly resulted in many new projects through concessions to Dubai Ports World (Algiers, Djen Djen) and to the Singaporean company Protek (Bejaia), there remain several limits to their implementation. Several laws in 1995, 1998, and 1999 on port privatization and reform have never been really fully applied in practice. After a socialist posture since the independence of the country in 1962, the sudden fall of profits from oil trade forced Algeria to adopt liberal measures in the 1980s. In the meantime, Algerian ports have been poorly modernized as explained above (MohamedChérif, 2007). A partial decentralization of the port sector occurs in 1982 with limited impacts, and is reinforced in 1998 by opening port services to the private sector, while in 2006 the State allows concessions with foreign private companies. Since then, results have remained highly uneven across the Algerian port system.

One first move towards the entry of private players in Algerian ports was made with the Bejaia Mediterranean Terminal (BMT) through a concession with Portek in 2005, which owns $49 \%$ of the joint-venture for a period of 20 years and an initial investment of US\$ 19 million. This deal was arranged despite the relatively limited experience of Portek in the specific container handling business (Benallegue, 2008). Strong support from local authorities to the concession is partly explained by a successful experience of concession in Bejaia in the agrofood sector with the Cevital group in 1998, which at that time constituted a unique example in the country. Besides the modernisation of ICT systems in the port, the BMT project has already proven its success by reaching satisfactory productivity rates: 20-25 containers an hour against 8-10 in Algiers. Traffic growth from 33,000 TEUs in 2005 to 150,000 TEUs in 2009 is largely explained by the project as well, notwithstanding new connections through short-sea shipping (cf. the MEDA MOS project). Along with the opening of a national school of port management in Bejaia, the project has already created 400 new jobs locally. While Bejaia has reached the second rank in the country's port container traffic after Algiers, it is able to evacuate containers more rapidly, i.e. within three days. Even some shippers in the automobile industry located in Algiers increasingly choose Bejaia for their imports 
(Mohamed-Chérif and Bellataf, 2010). Overall, Bejaia port itself has invested US\$200,000 on training and ICT, while a regular railway shuttle connects the dry ports of Benimansour in Bordj Bou Arreridj three times a week.

Long seen as a costly and low profitable port, Djen Djen - 350 kilometers East of Algiers - is officially a bulk port but its main client, a local steelworks, has never been opened. The port thus has often been used at maximum $25 \%$ of its real capacity despite the high cost of its construction, although it has succeeded in the export of dry cargoes such as cereals. Its good nautical accessibility (deep water) has been a key factor in its election by Dubai Ports World as it is able to welcome vessels of about 120,000 tons, but it is also well connected to the hinterland by highway (East-West) and railway. A concession of thirty years was thus signed to expand the current quay of 200 meters and 14 hectares with an additional 78 hectares, through an investment of US\$ 70 million as well as additional US\$ 150 million for related infrastructures and facilities, the total investment being about US\$ 500 million. The terminal should handle 1.5 million TEUs in 2020 against 100,000 nowadays while employing 1500 people. Such an investment coincides with the wish of Algeria to develop its own transhipment hub competing with Tangier, but also with the strategy to increase hinterland penetration towards Niger through a better access to the Trans-Saharan corridor. The group AREVA currently has plans to use Djen Djen for exporting uranium extracted at Imouraren in the North of Niger (Jeune Afrique, 2010). But still in 2013, Djen Djen port handles less than a thousand containers (Table 3).

After long and difficult negotiations started in 2006 due to protests from domestic dockworkers, a concession of thirty years has been signed in 2009 between the Entreprise Portuaire d'Alger (EPAL) and Dubai Ports World (DPW). The Emirati group was engaged to invest about US\$100 million during the first five years in the modernization of Algiers container terminal and to add 500,000 TEUs to its current capacity (currently 800,000 TEUs). Another agreement was to equip the terminal with four brand new gantry cranes at the condition that the Algerian State would extend the port area from 12 to 18 hectares, along with the provision of training programs on port management in Dubai offered to local employees. However, two years after the signature, Algiers' port activity has not much changed, given the still long waiting times of container vessels (about 21 days). This has a lot to do with delays in the planned extension of the port area as well as to wider national political factors. Indeed since 2005 large-scale projects have been launched throughout the country in all economic sectors, including the port sector during the US\$230 billion first fiveyear plan (2005-2009) with 21 different projects. A closer look at the nature of the projects 
reveals that most of them concern the maintenance of existing port infrastructure. A second five-year plan of US\$ 286 billion (2010-2014) includes about US\$ 42 billion for all construction-related projects, most of it being in the road sector. As such, among the 13 portrelated projects, ten focus on the maintenance of existing infrastructure and three concern the expansion of Oran container terminal as well as dredging operations in other ports except Algiers. There is clearly in the case of Algiers a mismatch between national plans and local dynamics. Recent traffic figures indicate that the share of DPW in Algiers port traffic has even decreased by $13 \%$ on the January-May 2011 period compared with 2010. However, while both EPAL and DPW have witnessed traffic decrease between the same periods, negative growth has been much higher for EPAL (-27\%) than for DPW (9\%) (Boughazi, 2011). Overall, the lack of experience of the Algerian State in public-private partnerships as well as general bureaucracy could lead to renegotiate the contracts with DPW.

\subsubsection{Tunisia: the new hub and free-zone of Enfidha}

The Enfidha project is planned to be constructed 75 kilometers south of Tunis, following the development of an international airport. The new port should cover about 1,200 hectares with deep water access as well as 2,000 hectares of logistics zone for a total capacity of 5.7 million TEUs and a cost of 1.4 million euros over 20 years. Two companies have answered the tender call in 2011, the Kuwait investment group Al Mal Investment Company KSC (allied of Hutchison Port Holdings) and the Canadian group SNC Lavalin. As for Djen Djen and Tangiers, the main objective of the port itself is to attract transhipment flows and to lower transport costs to and from Tunisia (Miossec, 2002).

\section{Maritime dynamics}

The review of port development projects across the Maghreb provides, overall, important evidences about the lack of an integrated strategy. Each country opted for its own projects of new port development and related free economic zones, in the hands of different global actors and serving their own national interests. However, the extent to which port and transport dynamics are reflected in the evolution of maritime flows within the Maghreb remains largely unexplored. This section explores how much interconnected are Maghreb countries and ports in two complementary ways: a long-term perspective focusing on all maritime flows, and a focus on container flows in recent years.

\subsection{Long-term evolution}


The extraction of vessel movement data from the Lloyd's Shipping Index published by Lloyd's List provided information about the last known voyage of each vessel between two ports at the date of the daily (sometimes weekly) publication. Due to technical difficulties only one paper publication was extracted for each selected year around the period April-May, between 1890 and 2008. Although this approach neglects a large proportion of other movements taking place during the rest of the year, it has the advantage of comparability over time. The method has been to count the number of vessel calls by port and by link between ports and to produce a diagram for each year starting in 1920 when intra-regional traffic is first appearing. The overall evolution since 1890 (Figure 4a) depicts a continuous increase in the number of vessel calls at Maghreb ports, with a peak activity reached in the late 1990s, the last drop between 2000 and 2008 following the world trend that is a reduction of port calls in a context of service rationalization. It also confirms that while intra-Maghreb maritime connectivity has always been rather limited, it was stronger in the past, with $13 \%$ of vessel calls in 1890-1965 being intra-regional on average against $8 \%$ for 1970-2008. Yet, this intraregional flows rest mostly upon domestic rather than trans-Maghreb flows (Figure 4b), the latter having oscillated around only 10 vessel calls along the period, after a peak in 19301935. Another important trend is the growing importance of the Mediterranean region in the distribution of maritime forelands, especially since the 1970s at the expense of Northern Europe, the Maghreb being increasingly dependent on external transhipment hubs for container flows since the mid-1990s.

[Insert Figure 4 about here]

A closer look at the distribution of domestic and trans-Maghreb maritime flows at the level of ports (Figure 5) provides interesting evidences about the detailed trends. The spatial evolution of the network reveals the influence of several factors alongside a shift from Algerian to Moroccan and Tunisian dominance. As suggested by previous Figure 4, trans-Maghreb connectivity had been strongest in the years 1930-1935. For Algeria, the disappearance of domestic linkages (coastal shipping) from 1975 onwards directly illustrates the implementation of a planned economy, by which the State exerts a monopoly and centralized control over all economic activities, up to nowadays. Wider economic trends also influence flows, such as for Algeria the decline in oil prices (1985-1986) that underlined the vulnerability of a mono-exporting country. The rapid decline of foreign investment caused a stagnation of the country's financial capabilities and its purchasing power thereby directly 
provoking a drastic slowdown of its maritime linkages. In fact, the recent growth of maritime activity is mostly distributed among bulk ports in recent years, Algiers remaining the domestic hub nationally. The tendency for higher connectivity to occur around each country's main city (Algiers, Casablanca, Tunis) is an interesting feature of the network, but this is better observed in the first half of the period and tends to shift towards bulk ports (outside main cities) over time.

Regionally, the creation of the Arab Maghreb Union (UMA) in 1989, which objective was to improve economic, political, and trade integration across the extended Maghreb (i.e. including Libya and Mauritania) did not foster stronger maritime linkages, especially since no official cooperation agreement has taken place after the last one in 1994. Weak maritime relations between Algeria and Morocco are partly due to (geo)political tensions. Although it is not mentioned in official documents, $41 \%$ of Morocco's LNG imports by sea came from Algeria in 2012, according to the Port Authority of Casablanca. The recent growth and diversification of maritime linkages between Morocco and Tunisia corresponds to the launch of the Agadir agreement (2004) whereby the two countries cooperate through the Agadir free-trade zone. Another factor is the development of the Motorways of the Sea policy since 2006 in the framework of the Union for the Mediterranean that promotes further regional integration in the Maghreb. Tunisia occupies a somewhat peculiar position in the network, with a pioneer role for attracting foreign investment (manufacturing) since the mid-1970s and the signature of a free-trade agreement with the European Union in 1995. This had also important effects on developing actively coastal shipping within the country.

[Insert Figure 5 about here]

\subsection{Recent evolution}

The methodology for analyzing recent maritime container flows slightly differs from the previous one, in a sense that it also includes linkages with non-Maghreb ports. It visualizes the graphs of inter-port linkages based on the daily movements of all container vessels for the month of May 1996, 2006, and 2011, still from Lloyd's List numerical data. It is in some way the "ego network" of the Maghreb, defined by a selection of Maghreb nodes and links between them and with other nodes, but excluding links among the other nodes. A look at the proportion of flows among Maghreb countries in their total maritime container flow 
respectively is useful before looking at the port level (Table 4). In 2006, most of vessel movements occurred within each country, except from Tunisia that witnessed the highest albeit moderate - share of its intra-Maghreb flows with Algeria (6\%). In 2011, the same situation occurred but now for all countries, so that the share of capacity and calls dropped from 25.6 and 28.1 to 8.2 and 20.9 respectively. The fact that capacity shares dropped much more than the number of calls is emblematic of a drastic loss in intra-Maghreb container trade, but this is largely due to lesser traffic within Algeria itself. Trans-Maghreb traffic has increased by more than 300\% between 2006 and 2011 for both capacity and calls. Nevertheless, this trend occurred in parallel with an increase of the share of Morocco in intraMaghreb flows, from $67 \%$ to $79 \%$ for capacity and from $59 \%$ to $84 \%$ for calls.

[Insert Table 4 about here]

The result at port level in 1996 (Figure 6) is striking: Maghreb ports are not connected at all in direct ways but only indirectly through common neighbors in the graph, such as Fos, Piraeus, Thessaloniki and Naples (Mediterranean ports) and Hamburg, Felixstowe, Rotterdam (North European range ports). Casablanca and Rades largely dominate by their central position in the network, with regard to their higher containerization rate overall than Algiers (see section 2). This situation is emblematic of the prevalence of political factors over intra-Maghreb linkages, which the logistical pattern fully illustrates. In 2006 (Figure 7), the situation has noticeably changed by the multiplication of direct linkages among Maghreb ports. The same three ports still dominate the network (Algiers, Rades, and Casablanca) but more other Maghreb ports have been inserted. The location of the common neighbors shows that indirect linkages through extra-Maghreb countries remain mostly Mediterranean, thereby suggesting a growing regional integration of Maghreb ports with each other and within the wider EuroMediterranean area. The overall system is also more balanced in favor of Algerian ports, thus echoing the impact of the intervention of foreign players and of port reform. In 2011 however, the picture has changed drastically, with Tangier exerting dominance far beyond the other Maghreb ports. The effect of the Tangier-Med strategy has been successful in creating a new global hub in the region. This explains for a large part the shift of trans-Maghreb traffics towards Morocco (Table 4), to such an extent that this trend relies, in the end, mostly upon transit trade, not real trade, among Maghreb countries. Algerian ports have lost ground compared with 2006, but also Tunisian ports. Yet, the location of common neighbors has expanded geographically up to East Asia as seen with Hong Kong and Beilun (China) being 
common neighbors of Tangier and Djen Djen, the latter Algerian port standing outside of the dense network. To some extent, this result also shows that Algeria has managed to internationalize its port functions much more than Tunisia. Yet, the overall pattern of the Maghreb port system, seen from the maritime side, suffers from acute vulnerability and weak internal linkages. Perhaps, however, growing transit trade among Maghreb ports and countries may pave the way towards deeper investigation and realization of trade integration in the future.

\author{
[Insert Figure 6 about here] \\ [Insert Figure 7 about here] \\ [Insert Figure 8 about here]
}

\title{
5. Discussion and conclusion
}

Current trends in the evolution of the Maghreb port system remain much contrasted. On the one hand, the number and scale of current port and transport development projects undoubtedly attest the efforts put on enhancing the Maghreb's position in the global transport system. On the other hand and despite many discourses on regional integration notably through transport and logistics, each country of the Maghreb seems to follow distinct pathways. In addition, current projects face a high unevenness in terms of their level of completion and activity. The Tangier-Med project has started its operations in 2007 and has recorded relatively good results with a total container throughput of 2.1 and 2.6 million TEUs in 2010 and 2011 respectively. In comparison, the projected hubs of Djen Djen and Enfidha are still in the realization or early phase, notwithstanding the problems of local-global governance in the former and the impacts of the global financial crisis and of the national political crisis on the latter. While port reforms still encounter difficulties in Algeria, plans for establishing a trans-Maghreb transport corridor remain hampered by both political and technical obstacles. The shift of African trades towards Asia (Chaponnière, 2010) thus seems to reinforce individualistic responses to the need for upgrading and diversifying Maghreb infrastructures and logistics systems. Without further regional integration in the transport and port sector, and sustained weaknesses in the industrial sector, our results point at the growing polarization of Maghreb traffic upon Tangier, whereby a majority of Maghreb ports remain secondary ports served by feeder vessels and ro-ro services for containers and general cargoes. The convergence among Maghreb ports via this new transhipment hub is, perhaps, a 
sign of change, with the potential of enticing "real" integration of the region, more than if each Maghreb country had continued to rely on external, non-Maghreb transhipment hubs.

\section{Acknowledgements}

The research leading to these results has received funding from the European Research Council under the European Union's Seventh Framework Programme (FP/2007-2013)/ERC Grant Agreement n. [313847] 'World Seastems'. Authors also would like to thank Olaf Merk (OECD-ITF) for his support on data collection, and the three anonymous reviewers for their useful comments.

\section{References}

Belhedi, A. (2005) La dynamique économique régionale en Tunisie, traits et tendances. Analyse structurelle-résiduelle, Cybergeo: European Journal of Geography, 310, http://193.55.107.45/articles/310.pdf (accessed December 2011).

Benabderrazik, H. (2008) Opportunities for logistical improvements through Maghreb integration, in G.C. Hufbauer and C. Brunel (Eds.) Maghreb Regional and Global Integration, pp. 139-148 (Washington: Peterson Institute for International Economics).

Benallegue, A. (2008) Concessions portuaires, mythes ou réalités ? Alger et Djen Djen dans la dynamique, Economia, 15, pp. 32-36.

Bensidoun, I., Chevalier, A. (1996) Europe-Méditerranée : le pari de l'ouverture (Paris: Economica).

Bost, F. (2010) Atlas mondial des zones franches (Paris: La Documentation Française).

Boughazi, S. (2011) Algérie : hausse du trafic portuaire à Alger, La Tribune, July 17, http://fr.allafrica.com/stories/201107181438.html (access August 2011).

Brooks, M., Cullinane, K. (2006) Devolution, Port Governance and Port Performance, Research in Transportation Economics, 17.

Brunel, C., Hufbauer, G.C. (2008) Reviving Maghreb integration: recommendations, in G.C. Hufbauer and C. Brunel (Eds.) Maghreb Regional and Global Integration, pp. 163-171 (Washington: Peterson Institute for International Economics).

Burmeister, A., Joignaux G. (1997) Infrastructures de transport et territoires. Paris: L'Harmattan.

CETMO (2005) Résultats obtenus de l'application du modèle "DESTIN" de prévision de trafics internationaux de marchandises, Paper presented at the International Conference on 
Containerization in Algeria, Bejaia, July 2-3, http://www.cetmo.org/pdf/Dossier63_fr1.pdf (accessed August 2011).

Chaponnière, J.R. (2010) Le basculement de l'Afrique vers l'Asie : enjeux pour les ports africains, Afrique Contemporaine, 234(2), pp. 25-40.

Chaudier, J. (2014) Tanger Med redessine les routes, Econostrum, May 23, http://www.econostrum.info/Tanger-Med-redessine-les-routes_a18168.html

Cherfaoui, N., Doghmi, H. (2005) Ports du Maroc des origines à 2020 (Casablanca: Sciences de l'Ingénieur).

Chouiki, M. (2009) Le port de Tanger Med : un tournant dans les dynamiques de restructuration des littoraux au Maroc, in B. Semmoud (Ed.) Mers, Détroits et Littoraux : Charnières ou Frontières des Territoires (Paris: L'Harmattan), pp. 163-174.

Corm, G. (1993) La réforme économique algérienne : une réforme mal-aimée, MaghrebMachrek, 139, pp. 9-27.

Côte, M. (1988) L'Algérie ou l'espace retourné (Paris: Flammarion).

Crozet, Y. (2009) Prospective des transports en Méditerranée à l'horizon 2030, Working Paper, Laboratoire d'Economie des Transports, Paris.

Debrie, J., Eliot, E., Steck, B. (2003) Mondialisation des réseaux de circulation en Afrique de l'Ouest, Mappemonde, 71(3), pp. 7-12.

Ducruet, C. (2008) Hub dependence in constrained economies: the case of North Korea, Maritime Policy and Management, 35(4), pp. 377-394.

Ducruet, C. (2010) Reti marittime e gerarchie portuali in Europa: un confronto tra Nord e Sud, L'Ingegnere, 30/34, pp. 18-25.

Ducruet, C. (2013) Network diversity and maritime flows, Journal of Transport Geography, 30: $77-88$.

Ducruet, C., Mohammed-Chérif, F.Z., Cherfaoui, N. (2011) Maghreb port cities in transition: the case of Tangier, Portus Plus, 1(1), http://www.reteonline.org/media/pdf/Portus-Plus2011/C\%C3\%A9sar\%20DUCRUET.pdf (accessed October 2011).

Ducruet, C., Zaidi, F. (2012) Maritime constellations: A complex network approach to shipping and ports, Maritime Policy and Management, 39(2): 151-168.

El Khayat, M. (2013) Autorités portuaires au Maroc après la réforme: enjeux de la régulation. (Marseille: Institut Méditerranéen des Transports Maritimes).

El Khayat, M. (2014) Transport infrastructure and logistics. The strategic levers of trade and competitiveness, In: Rollet, A. (Ed.) CIHEAM, Mediterra 2014. Logistique et commerce agro-alimentaire, un défi pour la Méditerranée (Paris: Les Presses de Sciences Po), pp. 
Fageda, X. (2000) Load centres in the Mediterranean port range: ports hub and ports gateway, Paper presented at the 40th Congress of the European Regional Science Association, Barcelona, Spain, 29 August-01 September.

Ferrari, C., Parola, F., Morchio, E. (2006) Southern European ports and the spatial distribution of EDCs, Maritime Economics and Logistics, 8(1), pp. 60-81.

Foschi, A.D. (2003) The maritime container transport structure in the Mediterranean and Italy, E-papers del Dipartimento di Scienze Economische, Universita di Pisa, Discussion Paper 24.

Fraser, D.R., Notteboom, T.E., Ducruet, C. (2014) Peripherality in the global container shipping network: The case of the Southern African container port system, Geojournal, DOI: 10.1007/s10708-014-9610-6.

Frémont, A. (2010) Les ports, leviers de développement ? Opportunités sur la rive sud de la Méditerranée, Afrique Contemporaine, 2(234), pp. 59-71.

Gouvernal, E., Debrie, J., Slack, B. (2005) Dynamics of change in the port system of the Western Mediterranean, Maritime Policy and Management, 32(2), pp. 107-121.

Hilling, D. (1969) The evolution of the major ports of West Africa, The Geographical Journal, 135(3), pp. 365-378.

Hilling, D. (1977) The evolution of a port system - the case of Ghana, Geography, 62, pp. 97 105.

Hoyle, B.S., Charlier, J. (1995) Inter-port competition in developing countries: an East African case study, Journal of Transport Geography, 3(2), pp. 87-103.

Invest in Med (2009) Investissements prioritaires pour le développement de la logistique en Méditerranée, Paper presented at the Salon International de la Logistique et de la Manutention, Barcelona, Spain, June 2.

Jeune Afrique (2010) Du 'yellow cake' à Djen Djen ?, April 2, http://www.jeuneafrique.com/Article/ARTJAJA2568p010.xml3 (accessed September 2011). Journal de la Marine Marchande (2010) Bilan Annuel des Ports du Monde, Wolter-Kleuwers. Lacoste, Y. (2007) L’Etat du Maghreb (Paris: La Découverte).

Lahlou, A. (2010) Quelques aspects environnementaux dans les pays du Maghreb (Morocco: ISESCO).

Jajugie, J., Delfaud, P., Lacour, C. (1985) Espace régional et aménagement du territoire. Dalloz, Paris. 
Lemarchand, A., Joly, O. (2009) Regional integration and maritime range. In: T. E. Notteboom, C. Ducruet, \& P. W. de Langen (Eds.), Ports in proximity: Competition and coordination among adjacent seaports (pp. 87-99). Aldershot: Ashgate.

Marei, N. (2008) Enjeux maritimes et portuaires du détroit de Gibraltar, Note de synthèse ISEMAR, 105, http://www.isemar.asso.fr/fr/pdf/note-de-synthese-isemar-105.pdf (accessed September 2011).

MEDA (2005) Vers un système intégré de transport euro-méditerranéen, Paper presented at the 1st Euro-Mediterranean Conference of Ministries of Transport, Marrakech, December 15. Miossec, J.M. (2002) Tunisie, métropolisation, mondialisation : efficience renforcée de l'axe oriental, Cahiers de la Méditerranée, 64, pp. 199-234.

Mohamed-Chérif, F.Z. (2007) Les ports algériens à l'heure du désengagement de l'Etat, La Revue Maritime, IFREMER, 480, pp. 1-5.

Mohamed-Chérif, F.Z. (2008) La situation actuelle des ports algériens, Bulletin de Liaison des Membres de la Société de Géographie, 2, pp. 21-28.

Mohamed-Chérif, F.Z. (2008) L'économie maritime algérienne et Euroméditerranée, La Revue Maritime, IFREMER, 483, pp. 58-64.

Mohamed-Chérif, F.Z. (2010) L'insertion territoriale du nouveau port Tanger Méditerranée, Paper presented at the 1st International Conference on Maghreb Ports, Bou Ismail, Algeria, 2-3 February.

Mohamed-Chérif, F.Z., Bellataf, M. (2010) La chaîne logistique du commerce mondial : gestion, sécurité et facilitations, le cas de l'Entreprise Portuaire de Bejaia, Paper presented at the International Conference on La logistique, clé de la compétitivité des entreprises, état des lieux et perspectives, El Djadida, Morocco, 5-6 May.

Mohamed-Chérif, F.Z., Ducruet, C. (2011) Les ports et la façade maritime du Maghreb : entre intégration régionale et mondiale, Mappemonde, 101, http://mappemonde.mgm.fr/num29/articles/art11103.html (accessed December 2011).

Ng, A.K.Y., Ducruet, C. (2014) The changing tides of port geography (1950-2012), Progress in Human Geography, 38(6): 785-823.

Notteboom, T.E. (2011) From multi-porting to a hub port configuration: the South African container port system in transition, International Journal of Shipping and Transport Logistics, 2(2), pp. 224-245.

Ocean Shipping Consultants (2009) Beyond the Bottlenecks: Ports in Africa, AICD Background Paper 8, August. 
Piermay, J.L. (2009) La frontière, un outil de projection au monde. Les mutations de Tanger (Maroc), Espaces et Sociétés, 138(3), pp. 69-83.

Planel, S. (2009) Transformations de l'Etat et politiques territoriales dans le Maroc contemporain, L'Espace Politique, 7, online article, http://espacepolitique.revues.org (accessed December 2011).

Reynaud, C., Decoupigny, C. (2008) L'intégration des réseaux de transport dans l'espace euroméditerranéen et le rôle du transport maritime, in X. Peraldi and M. Rombaldi (Eds.) Le transport maritime à courte distance : enjeux et perspectives en méditerranée, pp. 79-111 (Paris: L'Harmattan).

Ridolfi (1999) Containerisation in the Mediterranean: Between global ocean routeways and feeder services, Geojournal, 48(1), pp. 29-34.

Rimmer, P.J. (2007) Port dynamics since 1965: Past patterns, current conditions and future directions, Journal of International Logistics and Trade, 5(1): 75-97.

Romagnoli, A., Mengoni, L. (2009) The challenge of economic integration in the MENA region: from GAFTA and EU-MFTA to small scale Arab Unions, Economic Change and Restructuring, 42, pp. 69-83.

Sanchez, R.J., Wilmsmeier, G. (2010) Contextual port development: A theoretical approach, in: Coto-Millan, P., Pesquera, M.A., Castanedo, J. (Eds.), Essays on Port Economics (Berlin and Heidelberg: Springer-Verlag), pp. 19-44.

Setti, M. (2001), La conteneurisation dans les ports algériens : évolution, contraintes et perspectives, Bulletin of the Egyptian Geographical Society, 74, pp. 123-142.

Taaffe, E., Morrill, E., Gould, R. (1963) Transport expansion in underdeveloped countries: a comparative analysis, The Geographical Review, 53, pp. 503-529.

Tourret, P. (2005) Les ports et les armements du Maghreb, Note de synthèse ISEMAR, 80, http://www.isemar.asso.fr/fr/pdf/note-de-synthese-isemar-80.pdf (accessed August 2011).

Troin, J.F. (2006) Le Grand Maghreb (Paris: Armand Colin).

Tur, G. (2009) La Tunisie dote Enfidha d'un port et d'un aéroport, Econostrum, January 8, http://www.econostrum.info/La-Tunisie-dote-Enfidha-d-un-port-et-d-un-aeroport_a506.html (accessed September 2011).

Ulied, A., Biosca, O. (2008) La situation socio économique et les infrastructures de transport au Maghreb, Annuaire IEMED de la Méditerranée, pp. 271-276.

Vigarié, A. (1979) Ports de commerce et vie littorale. Paris: Hachette.

Weigert, M., Abeille, M. (2010) Les autoroutes de la mer : des perspectives prometteuses en Méditerranée, Les Notes de l'IPEMED, 7, February, Paris. 
World Bank (2007) Connect to Compete. Trade Logistics in the Global Economy: The Logistics Performance Index and its Indicators, http://siteresources.worldbank.org/INTTLF/Resources/lpireport.pdf (accessed December 2011).

Zohil, J., Prijon, M. (1999) The MED rule: the interdependence of container throughput and transhipment volumes in the Mediterranean ports, Maritime Policy and Management, 26(2), 175-193. 
Table 1: Port traffic structure of Algeria in 2011 (Unit: metric tons)

\begin{tabular}{|l|r|r|r|r|r|r|}
\hline & Inbound & \multicolumn{1}{|c|}{$\%$} & Outbound & \multicolumn{1}{|c|}{ Total } & \multicolumn{1}{c|}{$\%$} \\
\hline Agricultural products & 16365097 & 43.4 & 463229 & 0.6 & 16828326 & 14.2 \\
\hline Combustibles and solid minerals & 419893 & 1.1 & 0 & 0.0 & 419893 & 0.4 \\
\hline Oil products & 8513207 & 22.6 & 77367304 & 96.1 & 85880511 & 72.6 \\
\hline Ores and metal products & 4181858 & 11.1 & 111221 & 0.1 & 4293079 & 3.6 \\
\hline Minerals and construction materials & 1571077 & 4.2 & 126599 & 0.2 & 1697676 & 1.4 \\
\hline Fertilizers and chemicals & 1076913 & 2.9 & 1257747 & 1.6 & 2334660 & 2.0 \\
\hline General cargoes and containers & 5567327 & 14.8 & 1218017 & 1.5 & 6785344 & 5.7 \\
\hline Total & $\mathbf{3 7 6 9 5 3 7 2}$ & 100.0 & $\mathbf{8 0 5 4 4 1 1 7}$ & 100.0 & 118239489 & 100.0 \\
\hline
\end{tabular}

Source: Ministry of Transport

Table 2: Total traffic of Algerian ports in 2011 (Unit: metric tons)

\begin{tabular}{|c|c|c|c|c|c|c|c|c|c|}
\hline \multirow[t]{2}{*}{ Port } & \multirow[t]{2}{*}{ Total } & \multirow[t]{2}{*}{$\%$} & \multirow[t]{2}{*}{$\begin{array}{l}\text { Growth } \\
2008-2011\end{array}$} & \multirow{2}{*}{$\begin{array}{l}\text { Total traffic } \\
\text { excluding } \\
\text { hydrocarbons }\end{array}$} & \multirow{2}{*}{$\%$} & \multirow[t]{2}{*}{$\begin{array}{l}\text { Growth } \\
2008-2011\end{array}$} & \multicolumn{3}{|c|}{$\begin{array}{l}\text { Traffic share excluding } \\
\text { hydrocarbons }(\%)\end{array}$} \\
\hline & & & & & & & Import & Export & Total \\
\hline Alger / Dellys & 8913299 & 7.5 & -27.8 & 4414346 & 13.6 & -47.5 & 54.7 & 29.0 & 49.5 \\
\hline Annaba & 5093497 & 4.3 & -12.8 & 4165942 & 12.9 & -23.2 & 81.4 & 82.6 & 81.8 \\
\hline Arzew / Béthioua & 52905265 & 44.7 & -14.3 & 257532 & 0.8 & 857.7 & 6.7 & 0.2 & 0.5 \\
\hline Béjaïa & 13605502 & 11.5 & -13.3 & 9393900 & 29.0 & 52.4 & 89.3 & 15.5 & 69.0 \\
\hline Djen-Djen & 3065629 & 2.6 & 44.6 & 2999055 & 9.3 & 44.3 & 97.8 & 100.0 & 97.8 \\
\hline Ghazaouet & 1404065 & 1.2 & 39.2 & 1338786 & 4.1 & 36.0 & 95.1 & 100.0 & 95.4 \\
\hline Mostaghanem & 1188987 & 1.0 & 14.7 & 1149324 & 3.6 & 15.6 & 96.6 & 100.0 & 96.7 \\
\hline Oran & 5048672 & 4.3 & 9.5 & 4965571 & 15.4 & 11.1 & 98.3 & 98.7 & 98.4 \\
\hline Skikda & 26113499 & 22.1 & 12.5 & 2831455 & 8.8 & 11.7 & 71.5 & 0.7 & 10.8 \\
\hline Ténès & 901073 & 0.8 & 48.1 & 843065 & 2.6 & 38.5 & 93.6 & 100.0 & 93.6 \\
\hline Total & 118239488 & 100.0 & -7.8 & 32358976 & 100.0 & 1.3 & 77.4 & 3.9 & 27.4 \\
\hline
\end{tabular}

Source: Ministry of Transport 
Table 3: Container traffic at Algerian ports, 2001-2013 (Unit: TEUs)

\begin{tabular}{|c|c|c|c|c|c|c|c|c|c|c|}
\hline Port & 2001 & 2003 & 2004 & 2007 & 2008 & 2009 & 2010 & 2011 & 2012 & 2013 \\
\hline Alger & 249327 & 354061 & 419823 & 530526 & 606181 & 641243 & 643409 & 690622 & 702936 & 737259 \\
\hline Annaba & 5387 & 10519 & 12578 & 33694 & 40399 & 53762 & 64900 & 93485 & 131022 & 138565 \\
\hline Arzew & - & 164 & 139 & 46 & 77 & 734 & 365 & 64 & 214 & 52 \\
\hline Béjaïa & 16034 & 19842 & 49305 & 99208 & 113979 & 151247 & 165158 & 190149 & 228738 & 249032 \\
\hline Djen-Djen & 287 & - & - & 1090 & 290 & - & - & 33 & 223 & 674 \\
\hline Ghazaouet & 1785 & 1869 & 2213 & 2710 & 3438 & 8299 & 15808 & 26143 & 32860 & 35097 \\
\hline Mostaghanem & 1725 & 5729 & 4284 & 3614 & 2261 & 3067 & 4005 & 6047 & 4448 & 3662 \\
\hline Oran & 46372 & 67036 & 115901 & 124380 & 145743 & 177464 & 198736 & 201229 & 208865 & 232161 \\
\hline Skikda & 32941 & 70983 & 112913 & 100305 & 108717 & 110050 & 108455 & 115293 & 110655 & 132290 \\
\hline Ténès & - & - & - & 143 & - & - & - & 7 & 1 & 1 \\
\hline TOTAL & 353858 & 530203 & 717156 & 895716 & 1021085 & 1148866 & 1200836 & 942183 & 1029665 & 1138400 \\
\hline Gini* & 0.695 & 0.711 & 0.674 & 0.654 & 0.656 & 0.637 & 0.621 & 0.597 & 0.580 & 0.571 \\
\hline HHI* & 0.525 & 0.482 & 0.399 & 0.397 & 0.398 & 0.366 & 0.345 & 0.329 & 0.308 & 0.299 \\
\hline
\end{tabular}

Source: Ministry of Transport

* excluding Djen-Djen and Tenes due to their uneven traffics

Table 4: Maritime container flows among Maghreb countries in 2006 and 2011

\begin{tabular}{|c|c|c|c|c|c|c|c|c|}
\hline & \multicolumn{3}{|c|}{ Vessel capacity (\%TEUs) } & \multicolumn{4}{c|}{ Vessel calls (\%) } \\
\hline 2006 & Algeria & Morocco & Tunisia & Total & Algeria & Morocco & Tunisia & Total \\
\hline Algeria & 32.7 & 2.3 & 1.2 & 36.2 & 30.2 & 1.9 & 1.4 & 33.6 \\
\hline Morocco & 2.8 & 14.1 & 0.2 & 17.1 & 3.5 & 22.1 & 0.2 & 25.7 \\
\hline Tunisia & 6.0 & 0.7 & 0.3 & 7.1 & 6.8 & 0.5 & 0.4 & 7.7 \\
\hline Total & 18.0 & 6.9 & 0.7 & 25.6 & 19.0 & 8.1 & 0.9 & 28.1 \\
\hline 2011 & Algeria & Morocco & Tunisia & Total & Algeria & Morocco & Tunisia & Total \\
\hline Algeria & 17.0 & 3.7 & 1.8 & 22.5 & 18.9 & 3.8 & 1.6 & 24.3 \\
\hline Morocco & 0.3 & 5.6 & 0.3 & 6.2 & 0.9 & 17.7 & 1.1 & 19.6 \\
\hline Tunisia & 5.5 & 9.1 & 12.9 & 27.5 & 3.7 & 10.8 & 11.2 & 25.7 \\
\hline Total & 1.9 & 5.5 & 0.8 & 8.2 & 4.2 & 14.7 & 1.9 & 20.9 \\
\hline
\end{tabular}

Source: own calculation based on Lloyd's List Intelligence 
Figure 1: Maghreb port throughputs, 1981-2013

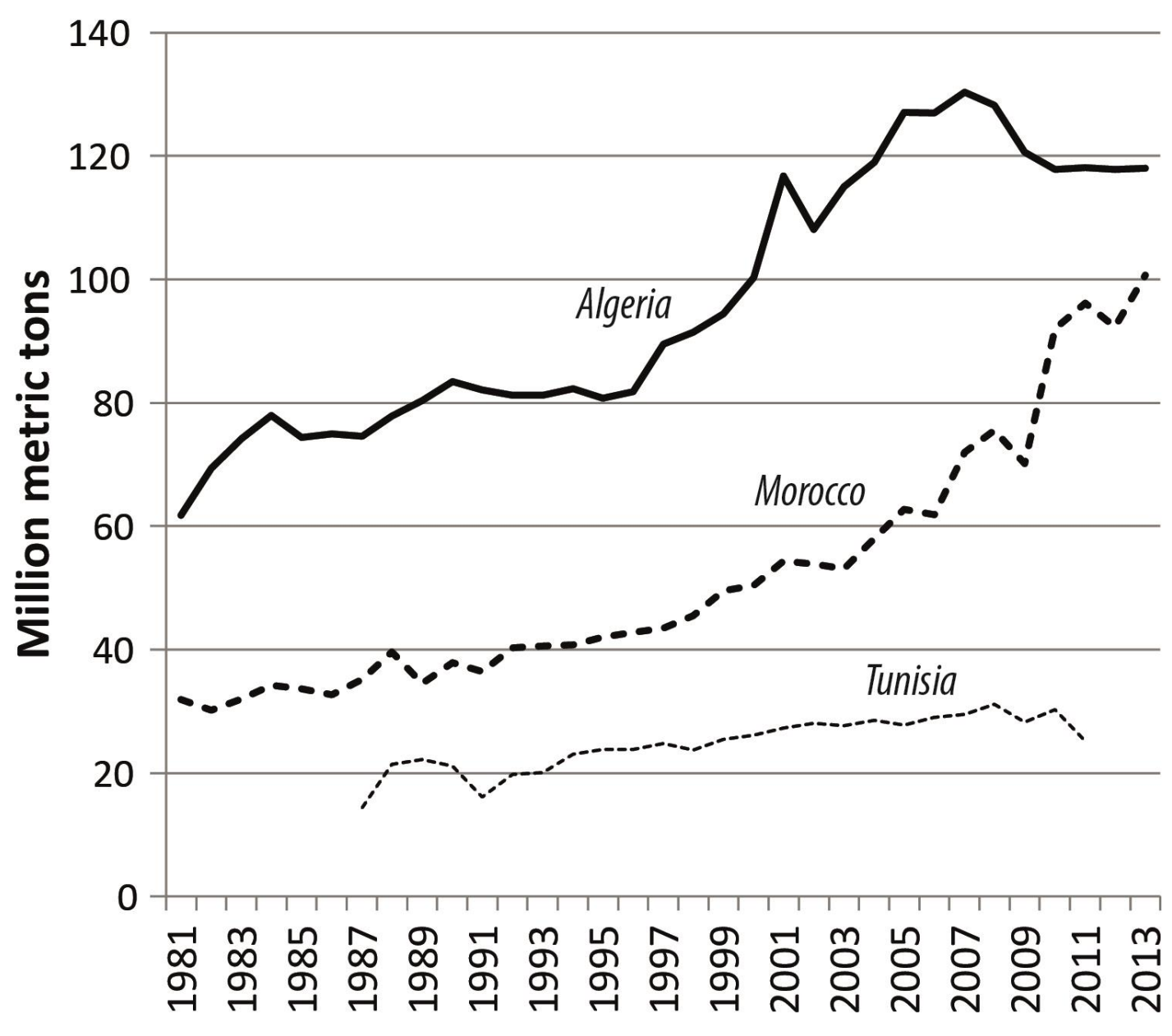

Source: own realization based on data from port authorities

N.B. data was missing for Tunisia for the years 1981-1986 and 2012-2013 
Figure 2: Algeria's port throughput, 1959-2013

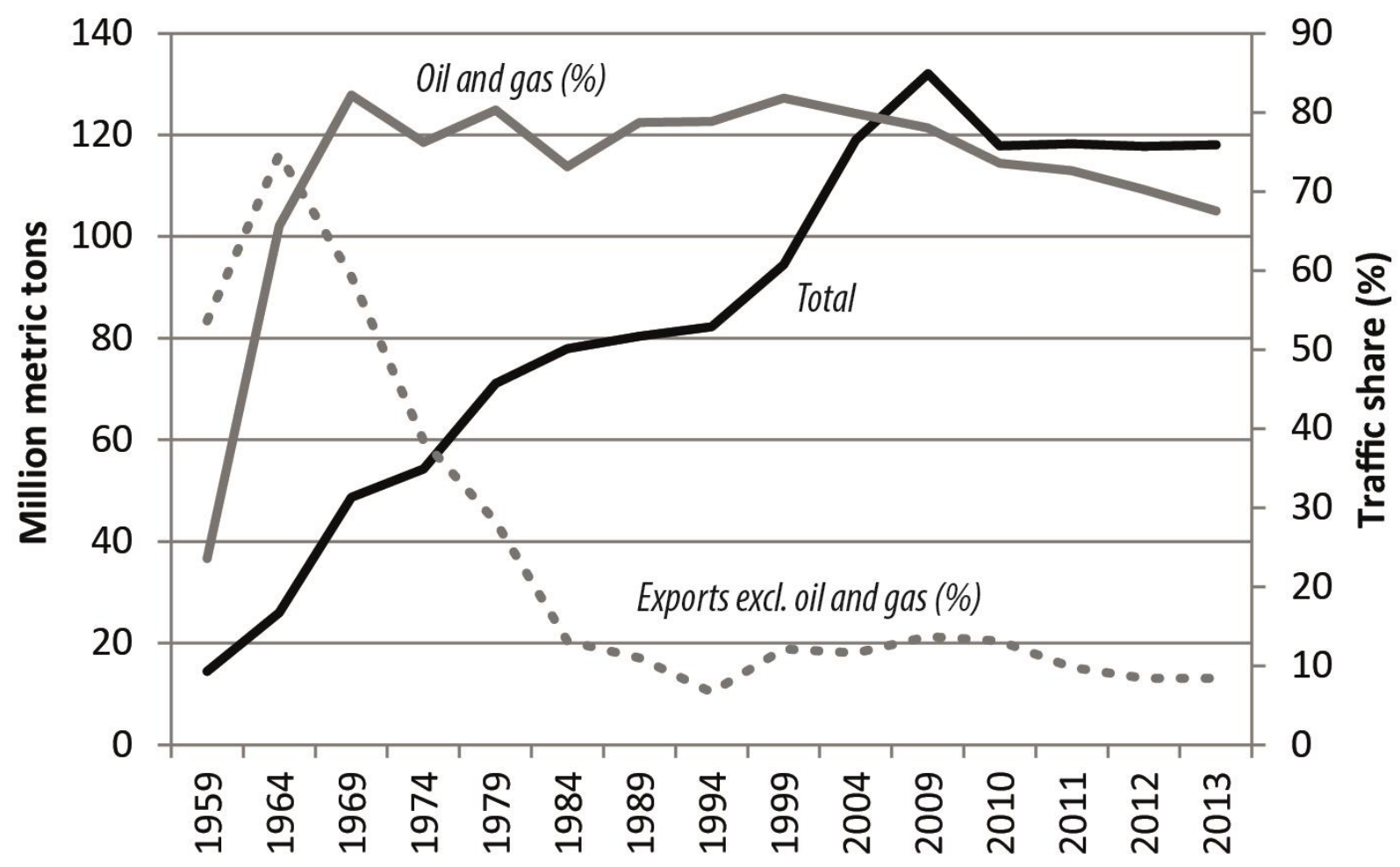

Source: own realization based on data from Ministry of Transport

Figure 3: The Maghreb transport system

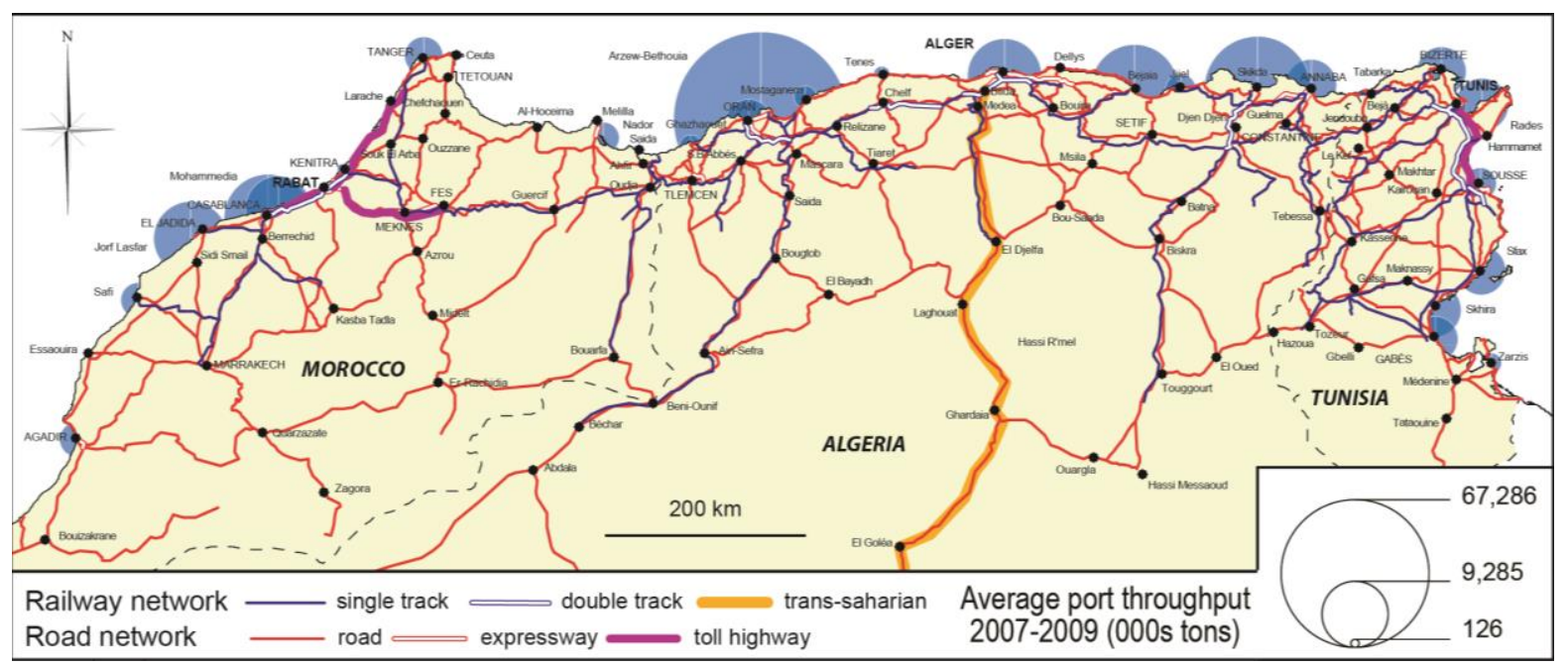

Source: own realization based on CETMO and Ministry of Transport 
Figure 4: Distribution of vessel traffic, 1890-2008
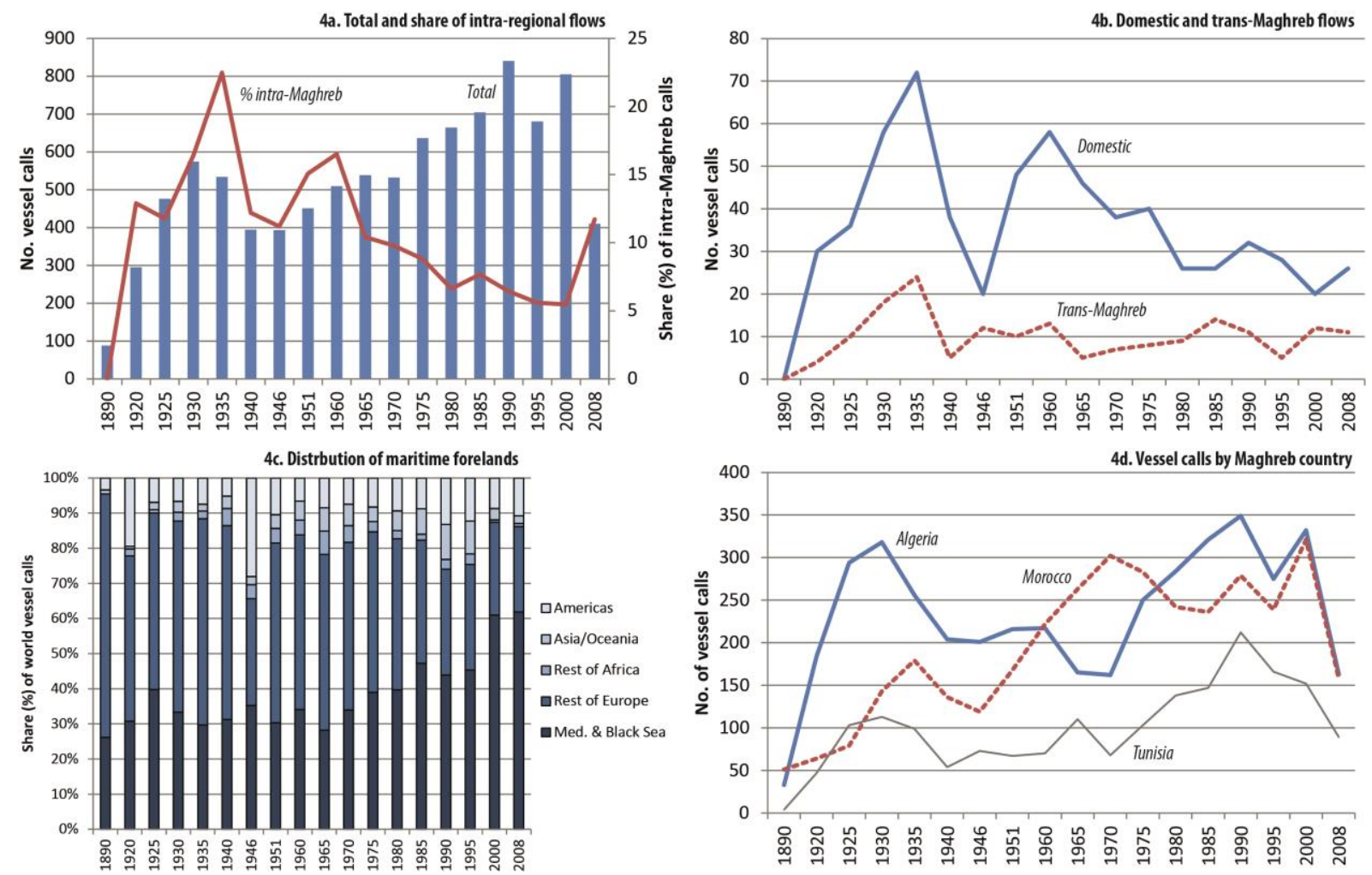

Source: own realization based on Lloyd's Shipping Index 
Figure 5: Evolution of maritime linkages among Maghreb ports, 1920-2008
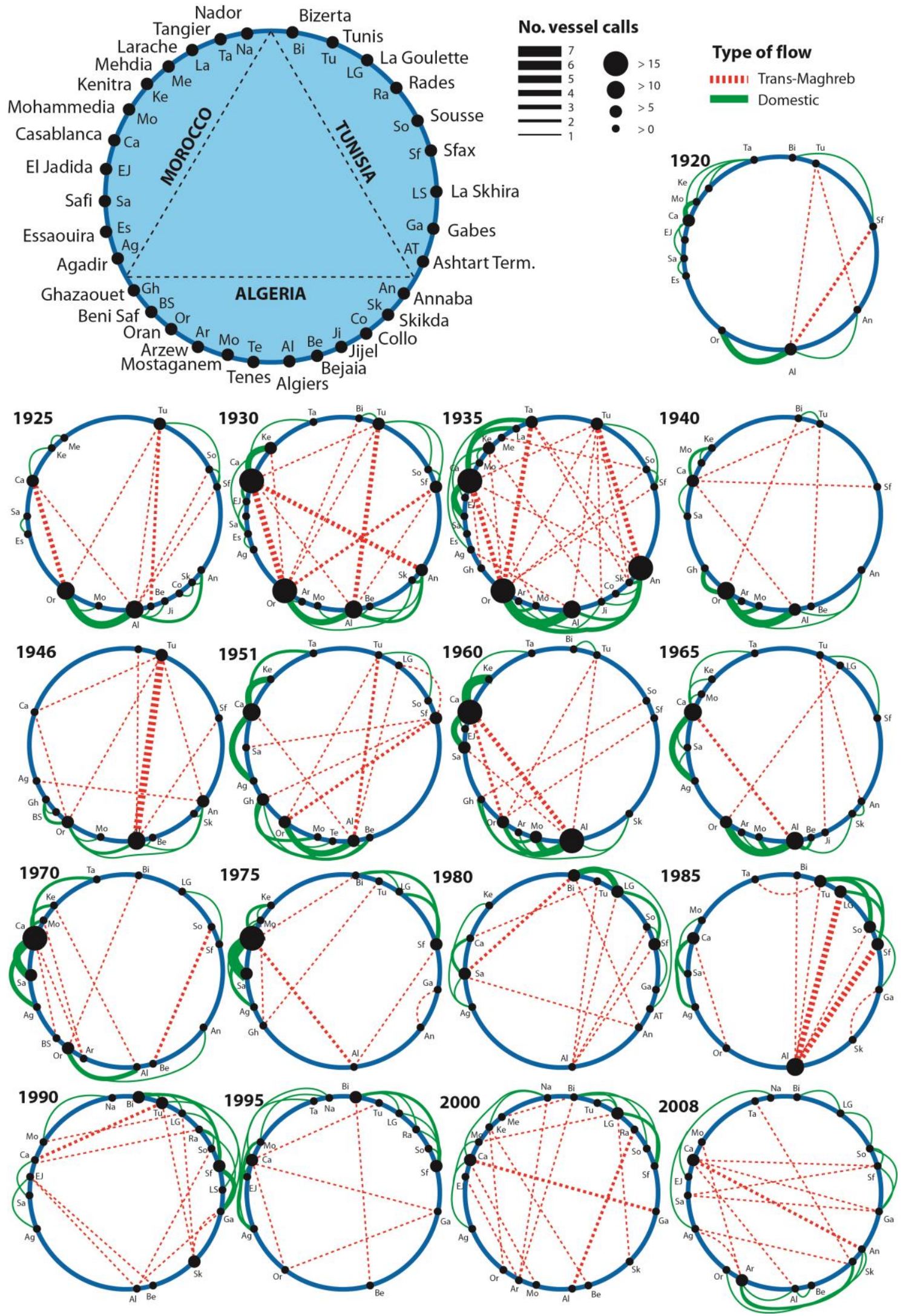

Source: own realization based on Lloyd's Shipping Index 
Figure 6: Maritime container flows, 1996

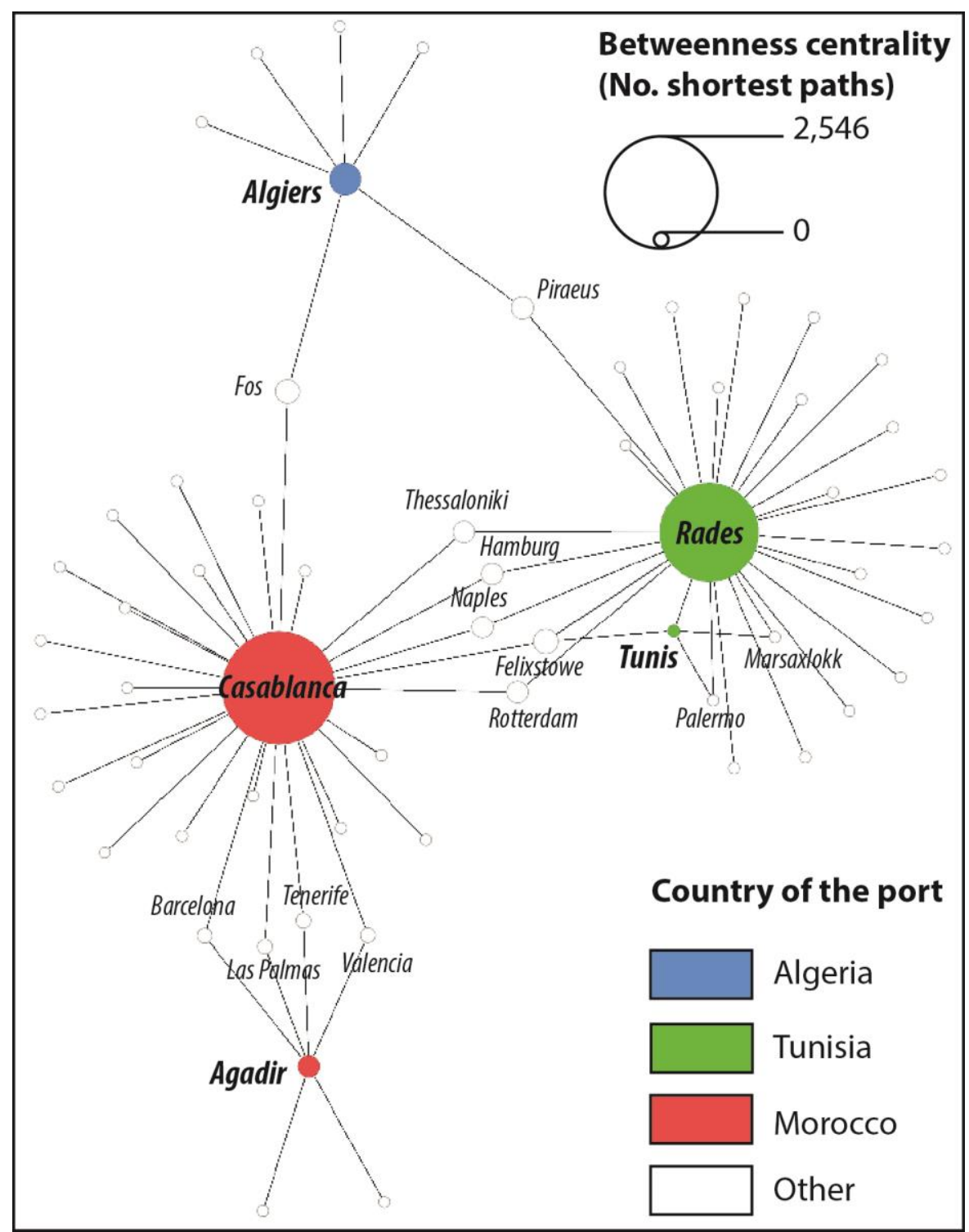

Source: own realization based on Lloyd's List Intelligence 
Figure 7: Maritime container flows, 2006

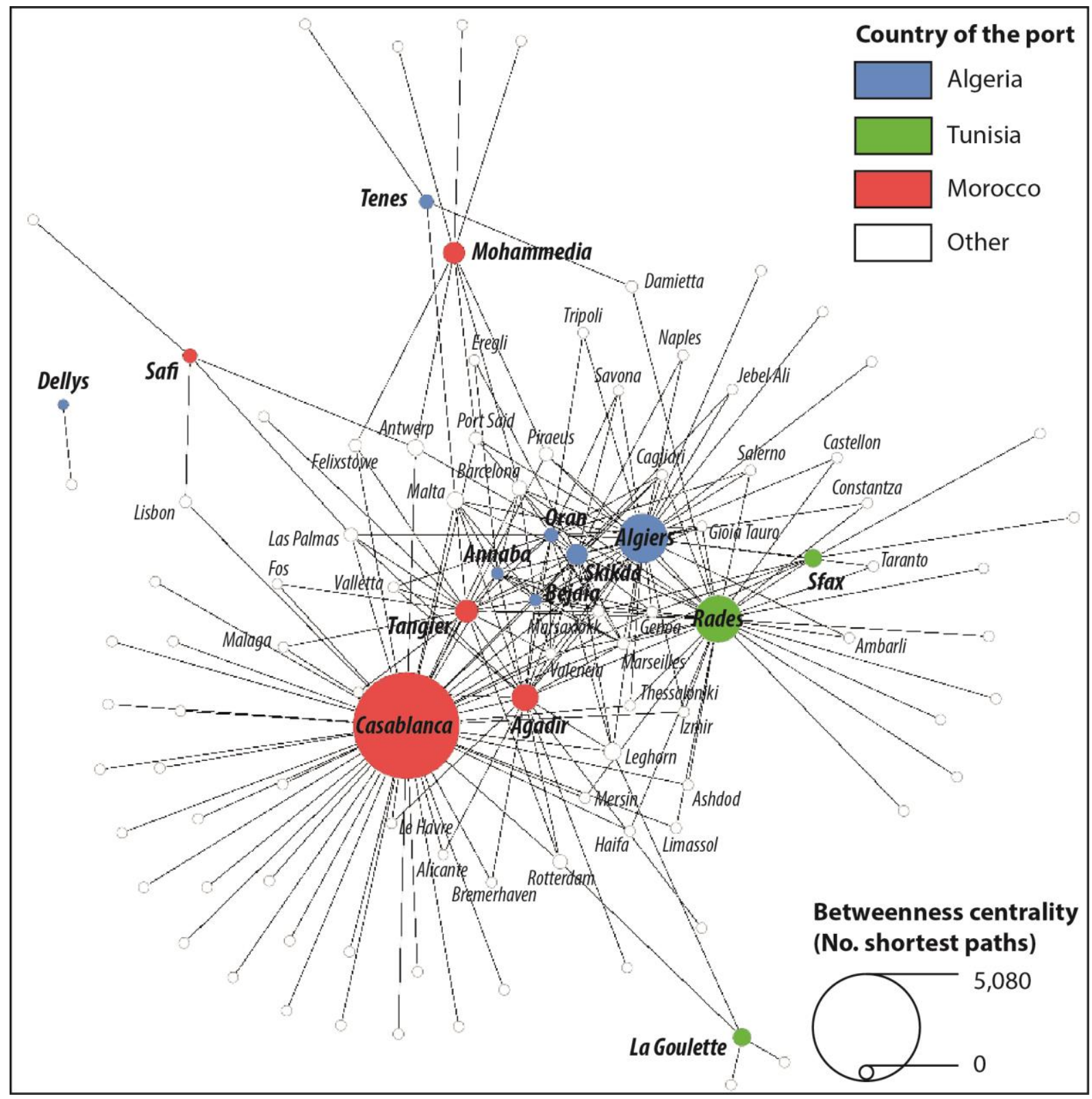

Source: own realization based on Lloyd's List Intelligence 
Figure 8: Maritime container flows, 2011

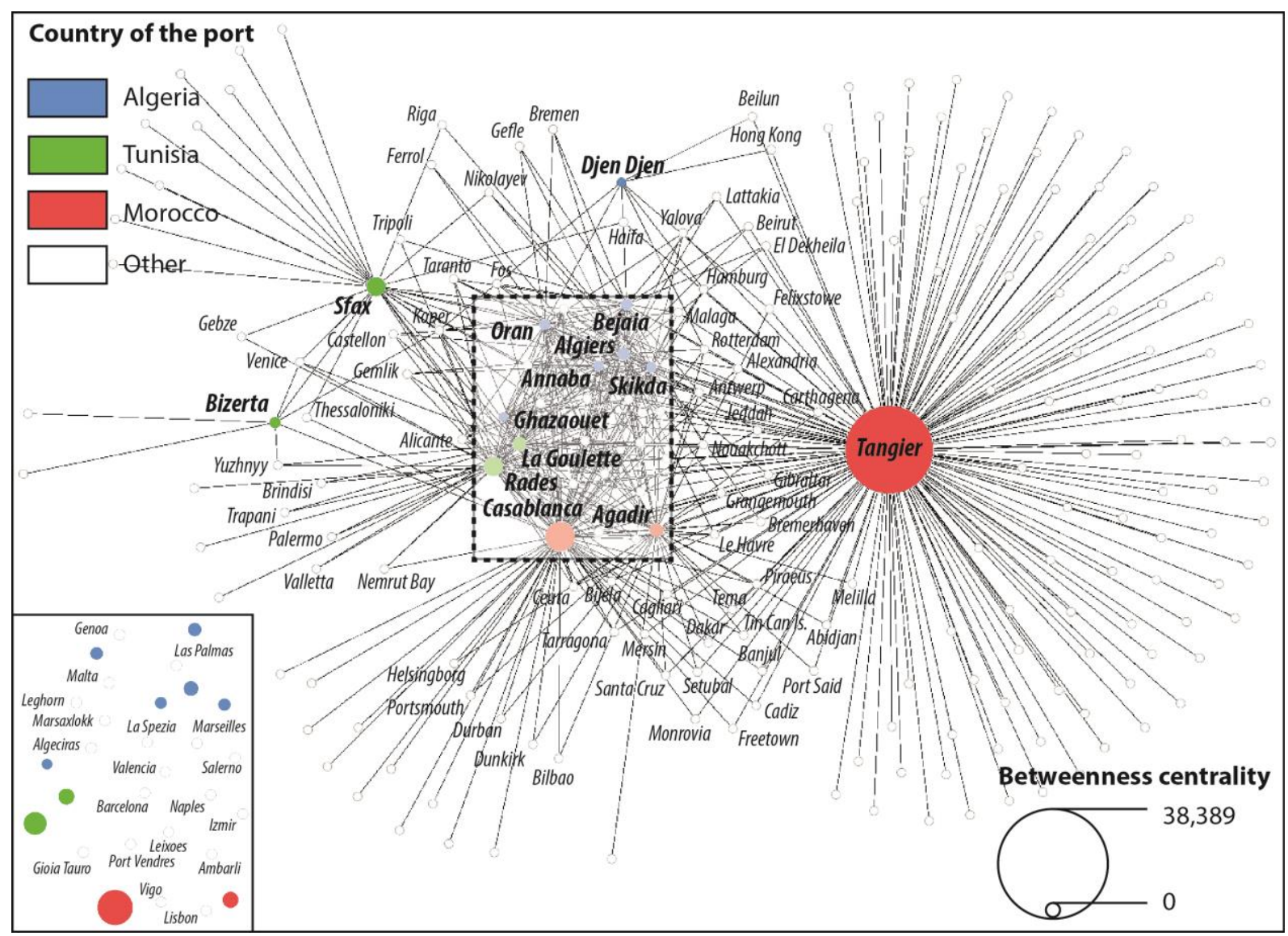

Source: own realization based on Lloyd's List Intelligence 